\title{
Osmanlı Dönemi Diyarbakır Hanları Üzerine Bir İnceleme
}

\author{
Nursel KARACA*
}

\section{Özet}

Geniş bölgeleri birbirine bağlayan ana yolların kesiştiği bir notada bulunan Diyarbakır, bu stratejik konumundan dolayı her dönemde önemli bir merkez niteliği taşımıştır. Osmanlı döneminde adını taşıdığı beylerbeyliğinin merkezi olarak bölgedeki önemli stratejik noktalardan biri olan Diyarbakır'daki Osmanlı eserleri, Güneydoğu Anadolu Bölgesi içinde Osmanlı kimliğini en güçlü yansıtan örnekler arasındadır. Üslubu, farklı malzemesi ve yapıya gösterilen özen sayesinde Diyarbakır mimarisi Anadolu'daki en çekici ve farklı mimari tarzlardan birini oluşturmaktadır. Osmanlı döneminde büyük bir eyaletin merkezi olan şehir zengin kültürel mirası ve doğal güzellikleri ile bir açık hava müzesi görünümünü yoğunlukla Osmanlı döneminde edinmiștir. Bu çalıșmada, Osmanlı döneminde Diyarbakır'ı ziyaret etmiș ve izlenimlerini eserleri yoluyla aktarmış olan seyyahların Diyarbakır hanları ile ilgili izlenimlerinden oluşan bilgiler eşliğinde Diyarbakır Osmanlı dönemi hanlarının genel hatlarıyla bir incelemesi sunulacaktır. Osmanlı dönemine ait bilgi ve belgelerin yeterince olmamasından dolayı, kenti çeşitli dönemlerde ziyaret eden seyyahların kent dokusu, mimari yapılar ve mimari doku üzerine verdiği subjektif bilgiler dikkatli okunduğunda bazı eksiklikleri giderecek niteliktedir.

Anahtar Kelimeler: Osmanlı Mimarisi, Diyarbakır Osmanlı Hanları, Seyahatnameler, Seyyahlar.

\section{A Study On The Inns Of Diyarbakır In The Ottoman Period}

\section{Abstract}

Diyarbakır, having been in the junction of the main roads that connects the wide areas, has always carried an important role of center in each period due to its strategical location. The Ottoman works in Diyarbakir, one of the important strategic point in the region as a center of state (province) bearing its name during the Ottoman era, are the most powerful examples reflecting the Ottoman identity in the Southeastern Anatolia Region. Diyarbakir architecture is one of the most attractive and different architectural genres in Anatolia by the agency of its style, its different material and The Solicitude shown to construction. The city, being a center of a huge province during the Ottoman era, has intensely adopted an open-air museum landscape with its rich cultural heritage and natural beauties in the Ottoman period. In this study, A review of Ottoman Inns will be presented in general terms with the information accompanied by the travellers who visited Diyarbakır in the Ottoman period and transferred their impressions through

* Yrd.Doç.Dr., Yalova Üniversitesi, Sanat ve Tasarım Fakültesi, nurselkaraca2004@yahoo. $\underline{\text { com }}$ 
their works about Diyarbakır Ottoman-era Inns. Because of the lack of enough information and documents belonging to the Otoman period, some subjective information on urban texture, architecture of the buildings and architectural texture of the city also beeing given by the travelers who visited the city during various periods have the quality of removing some defects when they have been read carefully.

Key Words: Ottoman Architecture, Diyarbakır Ottoman Inns, Travel Books, Travellers.

\section{Giriş}

Eskiden kentlerde konaklama yapısına 'Han' denilmekteydi. Hanlar, kentlerin ulaşım sistemine ve ticaret bölgelerinin konumuna göre önemli noktalarda konumlandırılmakta, kervanların ya da yolcuların güvenle konaklamaları için yapılmaktadır. Anadolu'da Selçuklu İmparatorluğunun egemenlik yıllarında düzenli çalışan bir yol sistemi bulunmakta, devrin kullanılan bütün yollarında belirli uzaklıklara hanlar yaptırılmıştı. Doğudan gelen kervanlar büyük bir güvenlikle Anadolu'yu geçtiklerinden bu yapılar uzun yıllar önemini korumuş, sayıları sürekli artmıştır. Bu sistem, Osmanlı İmparatorluğu'nun uzun idaresi süresince de aynen sürdürülmüş, yapımları, aynı Selçuklu İmparatorluğu döneminde olduğu üzere sultanlar ve devrin ileri gelen kişileri aracılığıyla gerçekleştirilmiştir. Osmanlı kent içi hanlarında, bedesten, arasta, çarşı gibi ticaret hayatının odaklaştığı mimari birimleri içermektedir. Bu yapılarda mal ve eşyanın depolanması, satılması yanında yolcuların, hayvanların barınması, çeşitli büro hizmetlerinin yerine getirilmesi gibi çeşitli işlevler yer almaktadır. Osmanlı kent içi hanları genellikle iki katlı olup zemin kat depo, ahır, onarım atölyeleri vb. servis kısımlarına, üst kat ise tümüyle yolcuların barınmasına ayrılmıştır. Yapının ortasında, her iki katta da revakların açıldığ 1 bir iç avlu bulunmaktadır. Kentsel dokunun yoğunluğundan dolayı düzgün dikdörtgen plan şeması giderek organik biçimler almıştır. Tek avlulu ve ahır kısmı avluya bitişik olan erken hanlardan, zamanla, yolcu odaları ve ahırları için birbirine bitişik ayrı avluları bulunan örnekler gelişmiştir. Yalınlığın ön plana çıktığı Osmanlı kent içi hanlarında sokak yönünde zemin katta dükkânlar bulunmaktadır. Malzeme olarak taş ya da almaşık olarak taş ve tuğla kullanılmıştır. Örtü sisteminde tonoz, kubbe, ahşap çatı ve bazen toprak dam uygulanmıştır. Ayrıca avlu ortasına bir şadırvan yerleştirilmiştir. İlk Osmanlı kent içi hanları Bursa ve çevresinde bulunmaktadır. Bursa'da Koza Han (16.yy. başı) bunlardan biridir (Yalçıner, 1997, s. 753).

\section{Osmanlı Dönemi Diyarbakır Hanları}

Önemli ticaret yollarının kavşağında yer alan önemli bir ticaret merkezi konumunda bulunan Diyarbakır ve çevresinde, birçok büyük kervansaray ve han bulunmaktadır. Günümüze ulaşanların çoğu Osmanlılar Dönemine aittir. 
Boyutları, bezemeleri ve mimari özellikleriyle ün salan bu yapıların bir kısmı, günümüzde de faaldir.

\subsection{Deliller Hanı}

Mardin Kapısı'ndan girilince hemen sağda yer alan büyük bir yapıdır. Diyarbakır'ın ikinci Osmanlı Valisi Hüsrev Paşa tarafından 1527-1528 (h. 934) yılında yaptırılmıştır. Hüsrev Paşa Hanı ya da "Kervansaray" (Akbulut, 1998, s. 58) olarak da bilinen yapıya Hicaz'a gidecek olan hacıları götürecek rehberlerin (delillerin) bu handa kalmalarından ötürü Deliller Hanı denilmiştir (Sözen, 1971, 1975; Köprülü, 1987; Ersoy, 1995; Yıldırım, 1996; Beysanoğlu, 1998; 2000 'e Beş Kala Diyarbakır, 1995; Altun, 1994).

Geniş bir alana yayılan han açık ve kapalı avlulu olmak üzere iki bölümden oluşmaktadır. Kare planlı, iki katlı ve avlulu bir yapıdır (Çiz.1). Yapı malzemesi olarak siyah ve beyaz kesme taş, moloz taş ve tuğla kullanılmıştır (Altun, 1994, s. 140). Giriş cephesi düzgün kesme taş, diğer cepheler kaba yonu taşla inşa edilmiştir (Baş, 2006, s. 190) (Res.1). Siyah-beyaz taş sıralarıyla hareketlendirilmiş ve cepheden taşıntılı taçkapı doğuya bakan giriş cephesinin ortasında yer almaktadır (Res.2-3). Basık kemerli kapı aracılığıyla bir hole girilmekte ve bu mekan şadırvanlı bir orta avluya açılmaktadır. Avlunun etrafını düzgün kesme taştan, kalın ayaklara dayanan iki katlı revaklar çevirmekte ve her bir revakın ardında birer han odası yer almaktadır. Hanın caddeye bakan kısımlarında alt katta boydan boya dükkanlar sıralanır. Diğer bölümlerinin iki katlı olmasına karşın, tek katlı olarak düzenlenen ahır bölümü güneye yerleştirilmiştir. Ahır ve depo olarak kullanılan bu kısma güney tarafta bulunan revak arkasındaki bir dükkân geçit vermektedir. Ahır bölümünde, beş ayak sırasını girişe paralel kemerler birbirine bağlamakta ve bu şekilde mekan altı nefe bölünmektedir. Doğu-batı yönünde uzanan kemerlerin aralarındaki nefler, boydan boya beşik tonozlarla örtülmüştür (Altun, 1994, s. 141) (Res.4). Ahır bölümünün önünde de dükkanlar bulunmaktadır. Giriş holünün ve tam karş1sında bulunan benzerinin iki tarafında bulunan ve sivri kemerli birer açılığıın içinde yer alan merdivenlerle bir müddet çıkıldıktan sonra sağlı ve sollu dönerek devam eden merdivenlerle ikinci kata ulaşılmaktadır. İkinci katta kalın ayakların taşıdığı revakların arkasında han odaları sıralanmıştır. Bu odaları revaklara derin kapılar bağlamaktadır.

Deliller Hanı 1950'li y1llarda geniş çaplı bir onarım görmüştür. 1982 yılında Vakıflar Genel Müdürlügü’’nün kararı ile restore edilerek turistik amaçlı kullanılmaya başlamıştır (Köprülü, 1987, s. 72). Bugün Kervansaray Oteli adı altında hizmet görmektedir. 
70 • YALOVA SOSYAL BİLIMLER DERGİSİ

\subsection{Hasan Paşa Hanı}

Hanın yapımına, Diyarbakır Valiliğine 1571 (H.978) yılında atanan Sokullu Mehmet Paşa'nın oğlu Vezir Hasan Paşa tarafindan başlanmış, Vali Hasan Paşa'nın başka yerde görevlendirilmesi sonucu bir sonraki Diyarbakır Valisi Özdemiroğlu Osman Paşa tarafından tamamlatılmıştır (Beysanoğlu, 2003, s. 618; 2000 'e Beş Kala Diyarbakır, 1995, ss. 66-67). 18. yy. ile 19. yy.'in ilk yarısında da Diyarbakır'ın en önemli hanlarından biri olduğu anlaşılan Hasan Paşa Hanı, Buckingham'ın 1815 yılı için verdiği bilgiler arasında hububat piyasasının burada toplandığı hakkındaki kaydı, 19. yy.'da da bu hanın büyük bir öneme sahip olduğunu belgelemektedir (1827, s. 214).

Dikdörtgen bir alanı kaplayan yapı iki katlı olarak düzenlenmiştir (Çiz.2). Avlu dikdörtgen bir formdadır. Revakların gerisinde odalara yer verilmiştir. Batı, güney ve doğuda bulunan birer kapı yapıya geçit sağlamaktadır. Batı yönde bulunan girişi Gazi Caddesi'ne, diğer girişleri ise hana bu yönlerden bitişik olan kapalı çarşılara açılmaktadır. Batı cephesinin altında beşik tonozlu dükkanlar yer almaktadır. Cephelerde siyah-beyaz iki renkli taşlar yatay olarak dizilmişlerdir. $\mathrm{Bu}$ durum zaten dikdörtgen biçimde olan yapının olduğundan da uzun görünmesine yol açmıştır. Cepheler yukarıda taş konsollar üzerine oturan bir silmeyle sonlanmaktadır (Res.5-6). Hanın ortasına baldaken tarzında bir şadırvan yerleştirilmiştir. Şadırvan altı sütuna dayanan sivri kemerlerle oluşturulmuş, kubbeyle örtülmüştür. Diyarbakır'ın ticaret merkezinde yer alan Han son dönemlerde restore edilerek halkın hizmetine sunulmuştur. Altta yer alan dükkanlar ve odalar işyeri ve alışveriş merkezi olarak, avlusu ise kafe ve dinlenme yeri olarak hizmet görmektedir (Res.7).

\section{3. Çifte Han (Borsa Hanı)}

Yapım tarihi kesin olarak bilinmemekle beraber eldeki belgelerden 16 . yy.'dan kalma Osmanlı Devri eseri olduğu anlaşılmaktadır (Sarı, 1996, s. 35; Beysanoğlu, 2003, s. 681). Eskiden borsanın tamamı, daha sonrada bir bölümü burada bulunmaktaydı. Bugün ise Eski Borsa kısmı otel olarak (Hotel Okan) kullanılmaktadır. Adının Çifte Han olması ikişer katlı iki yapıdan oluşmasindandir.

Çifte Han, doğu-batı doğrultusunda uzanmaktadır (Çiz.3). Yapının tamamı Diyarbakır'ın yaygın malzemesi olan siyah kesme bazalt taşından yapılmıştır. İki yapıdan oluşan handan birinin Cumhuriyet dönemi ile birlikte, 1940'11 yıllarda yol çalışması sırasında yıkılarak kısmen genişletilen yola katıldı̆̆ 1 , geri kalan kısmında da dükkanlar yapıldığ 1 (Beysanoğlu, 1996, s. 657) belirtilmektedir. Hanın giriş kısmı geniş kemerli derinliği fazla olmayan bir niş içine yerleştirilmiştir. İkinci kat buradan dışarı çıkıntı yapmıştır. Siyah kesme 
taşlarla döşeli avlunun üç tarafinda bu sütunlara dayanan basık revaklar yer aldığı halde, batıya bakan cephesinde revaklar yapılmamıştır. Revaklar her iki katta da aynı biçimde tekrarlanmıştır. Revak araları geniş hafif sivri kemerler şeklindedir. Revakların arkasında da han odaları yer almaktadır. Bu odalar dışarıya üstü düz hatıllı bir kapı ve bir pencereyle açılmaktadır. Hanın doğu cephesi düz duvar halindedir. Güney cephesi de etrafında yer alan yapılarla kapatılmıştır. Hanın bitişiğindeki yıkılmış kısma geçişin geniş sivri bir kemerle sağlandığ 1 ifade edilmektedir (Sözen, 1971, s. 201) (Res.10). Birçok yeri yıkılan ve eski halinden pek çok şey kaybeden Çifte Han bugün otel ve depo olarak kullanılmaktadır.

\section{Değerlendirme}

\subsection{Hanlarda Plan Ve Mekan Anlayışı}

Önemli ticaret yollarının kavşağında yer alan önemli bir ticaret merkezi konumunda bulunan Diyarbakır ve çevresinde, birçok büyük kervansaray ve han bulunmaktadır. Günümüze ulaşanların çoğu Osmanlılar Dönemine aittir. Boyutları, bezemeleri ve mimari özellikleriyle ün salan bu yapıların bir kısmı, günümüzde de faaldir. Bugün ayakta olmayan hanların kent içindeki konumlarına bakılacak olursa; Zincir Han'ın (1837) İçkale'de olduğu, Rüstem Paşa (Yenikapı) Hanı'nın (1539-1542) Yenikapı'nın dıştan girerken să̆ tarafinda bulunduğu, Alaca Han'ın (1676) Yeni kapı yakınlarında olduğu, Börekçiler Hanı'nın (1799) büyük ihtimalle Ulu Cami yakınlarında olduğu, Karakaş Hanı'nın (1800) Palancılar Çarşısı'nda olduğu, Kayseriye Hanı'nın, İskender Paşa Camii ile Yeni Hamam yakınlarında bulunduğu, İpekoğlu Hanı'nın İskender Paşa Camii'nin batısında ve Penbeciler Çarşısında olduğu, Han-1 Cedîd'in, (Şubat ortaları 1569-Behram Paşa) Behram Paşa Cami'nin arka tarafında bulunduğu, Melek Ahmed Paşa Hanı'nın, Urfa Kapısı yakınlarında bulunduğu, İbrahim Paşa Hanı'nın, Salos Mahallesi'nde, Muallak Mescidi'nin alt tarafında ve Deva Hamamı yanında olduğu, tütün Hanı'nın ise Abdal Mahallesi'nde, Deva Hamamı'nın bitişiğinde ve arkasında olduğu söylenmektedir (Yılmazçelik, 1999, ss. 475-476).

Eski yazarlar sefere giden orduların konakladığı, kervanların ve gezginlerin devamlı geçit yeri olan Diyarbakır'ın bu yapılarından bahsetmektedirler. Çoğunun birleştikleri nokta, bu yapıların ender bulunan yapılar olduğudur.

1612'de Diyarbakır'a gelen ve kentte Hasan Paşa Hanı'nda kalan Simeon Seyahatnâme'sinde hanın büyüklüğünden ve süslemelerinden söz ederek gözlemlerini “Şehre girdikten sonra Hasanpaşa Hanı'na indim. Muazzam kargir bir bina olan bu hanın 500 beygiri barındırabilen yer altında iki büyük ahırl, rengarenk demir bir parmaklıkla çevrilmiş çok güzel bir havuzu, üç kat 
üzerinde birçok kargir odaları vardı" (Andresyan, 1964, ss. 98-99) şeklinde aktarır. Evliya Çelebi seyahatnamesinde, hanlar konusunda diğer seyyahlara göre çok daha geniş bilgi vermekte ve Diyarbakır hanlarını şöyle sıralamaktadır: "Karbansaraylarından Melek Paşa Hanı, Rum kapısının iç yüzünde olup, şeddadvari kargir bir güzel binadır ki, güya henüz üstad elinden çımıştır. Bütün kubbeleri kurşun ile örtülü, dinlenecek mamur bir handır. Ama yazık ki, Diyarbekir valilerinin delileri burada oturur. Eğer uslu adamlar oturaydl, bu misafirhane, minnetsiz bir cennet kössesi olurdu." Karbarsaray1, at pazarı: "Bunun da bütün kubbeleri has mavi kurşun ile örtülü olup tarifinden insan acizdir. Burada da paşanın sekban ve sarıcaları otururlar. Kendilerinden başka bir adam gelip bu kervansaraya girse, sekbanlar köpek gibi o adamın üzerine üşüsüp parça parça ederler. Sarıcalar görse, sarı arı gibi sarılıp adamı sokarlar." (1970, ss. 128-129) Evliya Çelebi Mardin kapısı dibindeki Bezirgân Hanı'ndan bahsetmektedir. Bezirgân Hanı da Hüsrev Paşa'nın yaptırdığı Deliller Hanı'dır (TDVİA, 1994, s. 468). Evliya Çelebi handan bahisle; "yaptıranları hakir Evliya'ca bilinmeyen Mardin kapısı yakınındaki (Bezirgan hanı) mamur olup, hanlar içinde bir güldür. Bekar odaları da lüzumundan fazladır" demektedir. Evliya Çelebi Diyarbakır'ın birçok hanları olduğunu belirterek, Hasan Paşa Hanı'ndan Hüsnü Paşa Hanı şeklinde bahsedip; "içlerinde kale gibi Hüsnü Paşa hanı gayet sağlam ve müstahkem" şeklinde özelliklerini sıralar (1970, s. 129). Tavernier, “Diyarbakır'ın onbeş dakika ötesinde, Iran'a giden ve oradan gelen kervanların Diyarbakır'dan ziyade orada dinlendikleri büyük bir kervansarayın bulunduğu bir köy vardır. Çünkü şehir kervansaraylarında oda başına ayda üç veya dört kuruş ödenirken, köy kervansarayında hiçbir şey ödenmez" (1678, s. 146) diyerek Diyarbakır şehir içi hanlarının kervanların konaklaması için oldukça pahalı yerler olduğunu söylemektedir. 18.yy.'ın ortalarında, 1766 senesi Mayıs'ında Diyarbakır'1 ziyaret eden Carsten Niebuhr, büyük hanın kubbelerinin kurşunla kaplı olduğunu aktarır (TDVİA, 1994, s. 468). Diyarbakır'daki Osmanlı dönemi hanlarının en görkemlisi ve ilgi çekeni şüphesiz Hasan Paşa hanıdır. Günümüze ulaşan hanlardan da kubbeli olanı bu han olduğuna göre Niebuhr'un büyük han olarak sözünü ettiği han Hasan Paşa hanı olmalıdır. 18. yy'da Diyarbakır'a gelen bir başka gezgin olan yazar İnciciyan, 1804'te basılan Ermenice kaleme alınmış Coğrafya adlı kitabında, Borsa Hanı olarak da bilinen Çifte Hanı, Diyarbakır'ın en büyük hanlarından biri olarak gösterir (Beysanoğlu, 1996, s. 216).

1815-16 yılında, Buckingham'a göre; kentte yaklaşık onbeş han ve kervansaray bulunmaktadır. Bunların en başta gelenleri, Hasan Paşa Hanı, Çifte Han, Yeni Han, Karakaş Hanı olmak üzere onbir tanesinin adını verir. Hasan Paşa Hanı özellikle iyidir ve Urfa'daki hanların hepsinden daha üstündür. 
Onun alt katında, genellikle mısır çarşısı bulunur. Avlusunda yer alan ve onu çevreleyen dükkanlar genellikle mal ve eşya ile doludur. Üst kattaki bölümler zenaat ve imalat yerleri barındırır. Seyyah bu ifadeyle, hanın iki katlı olduğunu ve ayrıca dokuma tezgahlarının Hasan Paşa Hanı'nda toplandığını bildirmektedir. Etraftaki odalar burada kalan seyyahların konaklamalarına biçim verir ve hepsinin üstünde haremler ya da burada geçici bir süre kalacak olan aileler için mutfaklı, ocaklı ve diğer iç rahatlı̆̆ 1 için gerekli olan şeyleri barındıran daha üst bir kat bulunmaktadır (Buckingham, 1827, s. 215; TDVİA, 1994, s. 468). Buckingham dokuma tezgahlarının Hasan Paşa Hanı'nda toplandığını belirterek kentin özellikle ipeklilerinden ve pamuklu dokumalarından, deriden mamul eşyalarından söz etmektedir. Buckingham 1815 yılı için, "Pazarlar öylesine düzgün bir plan üzerinde değildir. Fakat üzerleri iyi örtülmüştür. Dükkânlar ağaç raflarla döşeli olup, mallar bütün özellikleri ile orada sergilenirler. Kasabanın imalatçılarının başlıca hammaddesi ipek ve pamuktur. Şehirde olan esnaflar şal, elbeceri aletleri, her renkten pipolar, altın ve gümüş tabakalar yaparlar. 1500 tezgah şal üretimi, 500 tezgah pamuk basıcısı, 300 deri imalatçısı, 100 demirci ve 50 pipo (ağızlık) yapımcısı vardır. Diyarbakır'da ilaç dışında bütün ihtiyaçlar kendi kaynaklarından temin edilebilmektedir..." (1827, s. 215) demektedir. Gerek Evliya Çelebi ve gerekse Buckingham'in vermiş olduğu bilgilerden, kentte çok hareketli bir ticari hayatın hüküm sürdüğü ve ipeğin 19.yy.'da da Diyarbakır'ın en önemli ticari ürünlerinden biri olduğu anlaşılmaktadır. Seyyaha göre, ... Hasan Paşa Hanı'nda, daha önce aynı şekilde Urfa'da yapıldığı gibi, yaklaşık beş yüz pamuk baskıc1s1 ve kumaş dokuyan yüz onbeş tezgah işlerini icra etmektedir. Üç yüz deri üreticisi, bunun yanında ayakkabı işiyle uğraşan, saraçlık yapan ve tüketime yönelik diğer branşlarla uğraşan imalatçıyı barındırmaktadır; yüz nalbant ve sadece yüz elli süslü pipo sap1 yapımcısı, bunun yanı sıra toprak gülleler, kehribar ağızlıklar vs. Burada tüketilen kıyafetler Halep yoluyla Avrupa'dan, cam/porselen eşya Almanya'dan elde edilir ve güzel müslin kumaşlar, kaşmir şallar, baharatlar ve ilaçlar Bağdat yoluyla Hindistan'dan elde edilmektedir. Fakat yerel ihtiyaçları içeren çoğu madde kentin kendi kaynaklarından elde edilebilir, her çeşit meyve ve bunların elde edilmesi bol ve ucuzdur ve kentin ortak ürünleri büyük insan topluluklarının talebini karşılamaya yeterlidir (Buckingham, 1827, s. 215).

1835-1839 y1lları arasındaki zaman dilimindeki Anadolu izlenimlerini anlatan Helmut Von Moltke'ye göre kentte birkaç kervansaray bulunmaktadır (1877, s. 233). Ebubekir Feyzi'nin Hulasa-i Ahvali'l-Buldan'da belirttiğine göre, 19. yy. başlarında Diyarbakır'da kentin içinde çok sayıda hanlar bulunmaktadır (Bulduk, 2008, s. 190). 19. yy'ın ortalarında Diyarbakır'ı ziyaret eden William Duckett, kesin bir sayı vermeden kentte çok sayıda kervansaray 
bulunduğunu söyler (Duckett, 1855, s. 261). 1856-57 yıllarında Diyarbakır'a gelen R.J. Garden Hasan Paşa Hanı'ndan 'Ulu Cami'nin doğusunda, ama yakınında, Hasan Paşa Hanı (ya da Kervansarayı) denen büyük bir bina bulunmaktadır. Siyah ve beyaz taş katmanlarından oluşan yapısı hoş bir etki yaratır" (1999, s. 142; 1867, ss. 182-193) şeklinde bahsetmektedir. 1881 y1lında Diyarbakır'ı ziyaret eden Amand von Schweiger-Lerchenfeld'e göre, ana caddenin (Gazi Caddesinden bahsediyor) yer aldığı kentin bu kısmında hareketli bir yaşam sürmekte, ticaret de bu cadde üzerinde bulunan çarşıda ve handa gerçekleşmektedir. Seyyah'a göre, sözü edilen hana (muhtemelen Hasan Paşa Hanı'ndan söz ediyor) Suriye ve Mezopotamya'dan kervanlar gelmekte ve burada yük indirmektedirler. Seyyah Acem Hanı düzenli bir han olarak niteleyip, yapının çeşit bakımından da çok zengin olduğunu belirtir. Ali Paşa Hanı'nda da çeşitli eşyalar satılmakta olup, han, seyyaha göre, aynı zamanda Asya Türkiyesi'nin en büyük hanı durumundadır (Pınar, 1999, s. 151; Schweiger-Lerchenfeld, 1882, ss. 322-324). 1890-1897 y1llar1 arasinda Diyarbakır'a gelen Edmund Naumann, şehri Dağkapı'dan güneydeki Mardinkapı'ya bağlayan anayol üzerinde sol tarafta görkemli bir kervansarayın yer aldığını söylerken belli ki Hasan Paşa Hanı'ndan söz etmektedir. Müştemilatının ve boyutlarının göz önüne alındığında büyük saray olarak adlandırılması gerektiği ama içinin karmakarışık ve pis olduğunu söylediği aktarilır. (Pınar, 1999, s. 159). Cuinet, 1891 'lerde kentte 19 han bulunduğunu bildirmektedir (1891, s. 380). Lord Warkworth'un da hanların girişinde çarşıların bulunduğu (1898, s. 233) bilgisini vermesi bize bu yapıların hem inşa edildikleri dönemde ve sonrasında kentin ticari alanında ne kadar etkin bir rol oynadıklarını, hem de bu dönemde Diyarbakır'ın ticari hayatının ne kadar canlı olduğunu kanıtlamaktadır. İran, Kafkasya ve Anadolu'yu gezen Charles Wilson da Diyarbakır çarşılarının güzel olduğundan bahsetmektedir (Parla, 1990, s. 16).

\subsubsection{Plan}

Osmanlı kent içi hanları genellikle iki katlı bir düzenlemeye sahiptir. Zemin kat depo, ahır, onarım atölyeleri gibi servis kısımlarına, üst kat ise tümüyle yolcuların barınmasına ayrılmıştır. Yapının ortasında, her iki katta da revakların açıldığı bir iç avlu bulunmaktadır (Yalçıner, 1997, s. 753). Diyarbakır'daki Osmanlı dönemi hanları biçimleniş şekilleriyle Osmanlı dönemindeki hanların genel şemasına uygun bir yapılanma göstermektedirler.

Deliller Hanı (Hüsrev Paşa Hanı) ile Hasan Paşa Hanı'nın her ikisi de dikdörtgen bir plan şeması göstermektedirler. İki katlı olan yapılardan Deliller Hanı'nın ortasında kareye yakın biçimli geniş bir avlu yer almaktadır. (Çiz.1, 
Res.2) Hasan Paşa Hanı'nın ortasında yer alan avlusu ise dikdörtgen formlu olup ortasında bezemesiz başlıklara oturan altı sütunla birbirine bağlanan almaşık örgülü hafif sivri kemerlerin baldaken anlayışta bir araya gelerek altıgen şeklinin oluştuğu üstü kubbeli bir şadırvan yer almaktadır (Çiz.2, Res.6-7) İkişer katlı iki yapıdan oluştuğu için Çifte Han adını alan yapı grubundan bugün geriye kalan han kareye yakın planlı, avlulu ve iki katlı şeklinde biçimlenmiştir. (Çiz.3, Res.8) Deliller Hanı (Hüsrev Paşa Hanı) ile Hasan Paşa Hanı'nda avlunun etrafını iki katta da revaklı bir sistem dolanır. Revakların arkasına da han odaları yerleştirilmiştir. Çifte Han'ın yapının ortasında yer alan avlunun üç tarafında basık kemerli revakları bulunmaktadır. Batı cephesine revaklar yapılmamıştır. Deliller Hanı'nda avlunun ortasında bir havuz, Hasan Paşa Hanı'nda ise bir şadırvan yer alır. Çifte Han'ın avlusunun ortasında bulunan sütun kalıntılarından burada da bir şadırvan bulunduğu anlaşılmaktadır (Res.9-10).

Osmanlı şehir içi hanlarının bir örneği olan Deliller Hanı geniş bir alana yayılmakta ve iki bölümden meydana gelmektedir. İlki iki katlı konaklama alanıdır. İkincisi ise, bunun güneyinde kalan, ana caddeye bakan ve yaklaşı 6-7 m. yüksekliğinde olan tek katlı ahır bölümüdür. Osmanlının erken dönem hanları tek avlulu olup, ahır kısmı avluya bitişik bulunmaktadır. Diyarbakır Deliller Hanı da bu özelliği bünyesinde barındırmaktadır. İstanbul merkezdeki hanlardan Kurşunlu (14.yy.), Burmalı (14.yy.), Rüstem Paşa (1561) ve Küçük Çukur Han (16.yy.) tek avlulu hanlara örnek teşkil eden erken dönem hanlarıdır.

Deliller Hanı, alt katın dış tarafinda yer alan dükkanları son derece gösterişli giriş bölümü ve havuzlu bir orta avlunun etrafında revakların yer alması ve bunların arkasında han odalarının yerleştirilmesiyle biçimlenmiştir. Hanın plan şekli, Osmanlı Hanları'nın genel plan şemasını tekrarlamaktadır. Genelden ayrıldığı nokta, siyah-beyaz taş sıraları ve süslemedeki bazı yenilikler şeklinde yerel mimari unsurlar bazında Güney-doğu Anadolu mimari geleneklerinin Osmanlı mimarisine olan katkısıdır. Hasan Paşa Hanı, han mimarisi içinde önemli bir örnektir. Yapının cephelerinde ve iç mekanda oldukça hareketli bir görünüme sahiptir. Şadırvanı, sütunlara dayanan revaklarıyla dış ve iç bir bütünlük arz etmektedir (Sözen, 1971, s. 198). Tek avlulu ve ahır kısmı avluya bitişik olan erken hanlardan, zamanla, yolcu odaları ve ahırları için birbirine bitişik ayrı avluları bulunan örnekler gelişmiştir (Yalçıner, 1997, s. 753). Çifte Han, bozulmadan bugüne kalabilseydi, Diyarbakır hanları içinde birbirine bitişik iki han şeklindeki formuyla diğerlerinden farklı nitelikte bir yapı örneği sunacaktı. Bu han, Deliller Hanı ve Hasan Paşa Hanı'na göre daha yalın bir görünüm sunmaktadır. 


\subsubsection{Mimari:}

Deliller Hanı'nda (Hüsrev Paşa Hanı), avluyu çevreleyen iki katta da revaklar, kalın ayaklara dayanmaktadır. Revaklar hafif sivri kemer açıklıklıdır. Hasan Paşa Hanı'nda avluyu iki kattada çevreleyen revaklar kenarlarda ayaklara, ortalarda ise sütunlara dayanmaktadır. Alt kat sütunları siyah taş, üst kat sütunları ise beyaz taştandır. Köşelerdeki ayaklar ise revaklarda da olduğu üzere bir sıra beyaz bir sıra siyah taştan almaşık olarak örülmüştür. Hasan Paşa Hanı'nın revakları hafif sivri kemer açıklıklıdır. Çifte Han'da, avlunun üç tarafını bezemesiz basık kemerli revaklar çevirmektedir. Her iki katta da aynı şekilde olan bu revaklar siyah taştan sütunlara dayanmaktadır. Çifte Han'ın revakları geniş basık kemer açıklıklıdır. İzmir Kızlarağası Hanı (1744), Mirkelamoğlu Hanı (18. yy.'ın son çeyreği) ve Urfa Merkez Hanları'ndan Barutçu Han ile Mençek Hanı'nın ikinci kat revaklarında revak kemerlerini desteklemek amacıyla sütun kullanıldığg belirtilmektedir (Özme, 2000, s. 79). Aynı düzen Diyarbakır Hasan Paşa Hanı ile Çifte Han'da da uygulanmıştır.

Diyarbakır'daki Osmanlı Dönemi hanlarında üst örtü elemanı olarak kubbe, tonoz ve düz dam kullanılmıştır. Tonoz ise beşik tonoz, aynalı tonoz ve çapraz tonoz şeklinde uygulanmıştır. Kubbelere pandantiflerle geçilmektedir. Deliller Hanı'nın (Hüsrev Paşa Hanı/Kervansaray), alt kısmında bulunan dükkânlar ve ahır kısmının önünde, Doğu-batı yönünde uzanan kemerlerin aralarındaki neflerin üzeri beşik tonozlarla örtülmüştür. Odaların köşelere rastlayanları ise aynalı tonozlarla örtülmüştür. Hasan Paşa Hanı'nın alt katında bulunan dükkânları beşik tonozludur. Han odalarının üstü ise kubbe ile örtülüdür. Hasan Paşa Hanı'nda, alt kat odalarını avluya bağlayan kemerler sivri kemer biçimindedirler. Han odalarının duvarlarına da birer kemerle bağlanmış olan revakların üstü çapraz tonozludur. Odaların üst örtülerinin anforalarla hafifletilmiş pandantifli kubbe olduğu ve bu tür anfora kullanımının Anadolu'da görülen eski bir geleneği temsil ettiği ve farklı dönemlere ait yapılarda rastlanabildiği ifade edilmektedir (Sözen, 1971, s. 198). Çifte Han'ın revaklar ve arkasında yer alan han odalarının örtü şekli düz damdır.

Deliller Hanı'nın (Hüsrev Paşa Hanı) giriş cephesi düzgün kesme taş, diğer cepheleri kaba yonu taşla inşa edilmiştir (Baş, 2006, s. 190)Deliller Hanı'nın (Hüsrev Paşa Hanı), cadde üzerindeki giriş cephesinde dükkânlar bulunmaktadır. Hanın giriş kapısının üzerindeki yazıda handa 17 dükkan bulunduğu belirtilmektedir. Dükkanların her birinin üzerine gelecek şekilde han odalarının birer penceresi bulunmaktadır. Bu pencereler yapının dört cephesinde de görülmektedir. Cepheler beyaz konsollara oturan bir sıra beyaz taşla oluşturulmuş bir silme ile sonlanmaktadır. Deliller Hanı'nın (Hüsrev Paşa Hanı), Giriş cephesinin ortasında siyah-beyaz taş sıralarıyla hareketlendirilmiş, cepheden 
taşıntılı bir taçkapı bulunmaktadır. Bunun iki yanında yer alan cepheler ise siyah kesme bazalt taştan örülmüş, dükkanların üzerinde bulunan kemerler ile pencerelerin yanları siyah-beyaz taşlarla almaşık örülmüştür. Diyarbakır Deliller Hanı'nın dış cephe saçakları küçük konsol dizisi üzerine oturmaktadır. Benzer saçakların Urfa Gümrük Hanı ile beraber 1563 tarihinde Urfa'da yaptırılan Dabakhane Camii'nde (Özme, 2000, s. 83) de uygulandığı ifade edilmektedir. Hasan Paşa Hanı'nın batı ve kuzey cephe dışındaki diğer cepheleri farklı yapılarla bağlantılıdır. Hanın bütün cephelerinde bezeme unsurları yer almaktadır. Batı cephesi siyah-beyaz iki renkli taşın almaşık biçimde örülmesiyle oldukça hareketli bir görünüme kavuşmuştur. Batı cephesi simetrik bir düzenleme göstermekte ve cephenin ortasında giriş eyvanı bulunmaktadır. Yapının üst kısmına doğru, dışa taşıntılı giriş kısmına göre daha alçakta kalan yan kısımlar iki katlı bir düzenleme göstermektedir. Altta dükkanlara ait yalın giriş kapıları, üstte ise altı̧ar pencere yer almaktadır. Hasan Paşa Hanı uzun bir cephe görünümüne sahiptir. Bu görünüm iki renkli taş sıralarının yatay olarak kullanılmasıyla daha da belirgin bir hal almıştır. Yine iki renkli olarak yapılmış ana kapı ve pencere kemerlerinde ise bu yatay çizgi kesilmektedir. Yapıyı yukarıda beyaz taş konsollara oturan siyah taştan bir silme sonlandırmakta ve geride han odalarının kubbeleri seçilmektedir. Deliller Hanı'nın dıştan tek yönde sınırlayan dükkânlar, ahır kısmının caddeye bakan yüzeyinde de devam etmektedir. Dışarıdan bakıldığında, ahır kısmı tek kat, odaların yer aldığı ana bölüm çift kat olarak yükselmektedir. Çifte Han'da, hanın doğu cephesi düz duvar halindedir. Güney cephesi de etrafında yer alan yapılarla kapatılmıştır. Hanın giriş cephesinde geniş kemer açıklıklı eyvan şeklindeki basit ve yalın kapısının bulunduğu giriş kısmının solundaki bölüm iki kısım halinde farklı düzenlenmiştir. Bunlardan ön cephede iç kısmın avlu bitimine kadar olan bölüme denk gelen kısımda, alt katta hafif sivri kemerli revaklar şeklinde dükkanlar yer almaktadır. İkinci katta alt kat kemerlerinin tam üzerine gelecek şekilde dört adet pencere yerleştirilmiştir. Ön cephede bundan sonraki kısımda alt katta gayet basık üç açıklığa yer verilmiştir. Girişin üstündeki kısım dışa taşıntılı olarak yapılmıştır. Girişin sağında yer alan kısım diğer kısımlardan daha yüksektir. Bu cephenin alt katında iki açıklık yer almaktadır. Üst katta dört adet pencere bulunmaktadır.

Diyarbakır'da Osmanlı dönemine ait şehir içi hanları olan Deliller Hanı ile Hasan Paşa Hanı'nda, pencereler oldukça büyük boyutludur. Hanların giriş kapıları üzerinde yer alan pencereler mukarnas kornişlerle kapatılan nişler içinde yer almakta, diğer pencereler genelde yerel etkiler altındaki bezemelere sahip dilimli kemerler ve sütunceler barındırmaktadır. Çifte Han'ın cephelerindeki pencereler farklı düzenlemelere sahiptir. Örneğin, ön cephe girişinin solunda bulunan ikinci katta alt kat kemerlerinin tam üzerine gelecek şekilde 
yerleştirilen dört adet pencere üç dilimli kemerle örtülmüş olarak yarıya kadar demir korkuluklu, Girişin sağında üst kattaki dört adet pencere dikdörtgen şeklinde yuvarlak kemerli ve demir şebekelidir.

Deliller Hanı'nda (Hüsrev Paşa Hanı), girişte ve giriş aksının tam karşısında bulunan kısımların iki tarafinda yer alan sivri kemerli açıklıkların içinde yer alan dokuzar basamakla bir sahanlığa ulaşılmakta, bundan sonra sağa ve sola dönen yine dokuzar basamakla ikinci kata ulaşılmaktadır. Hasan Paşa Hanı'nda alt kat avlu zemininden yüksekte tutulmuştur. Bu nedenle girişin tam karşısında bulanan kısıma dört merdivenle ulaşılmakta bundan sonra sağda ve solda bulunan kemerli kısmın içindeki dokuz merdivenle sahanlığa ulaş1lmakta ve yine bu merdivenler sağa ve sola dokuzar merdivenle ikinci kata ulaşımı sağlamaktadır. Giriş kısmında da eyvandan girildikten sonra sağda ve solda üç basamakla sivri kemerli merdiven açıklığına ulaşılmakta buradan da yine dokuz basamaklı merdivenle sahanlığa ulaşılmakta buradan sağa ve sola dönülerek dokuzar basamaklı merdivenle ikinci kata varılmaktadır. Çifte Han'da, mevcut hanın giriş kapısının biraz ilerisinde soldaki 15 basamaklı taş merdiven üst katla bağlantıyı sağlamaktadır. Bu merdivenlerin dışında, üst katla bağlantıyı sağlayan ikinci bir çıkış yeri bulunmamaktadır.

Deliller Hanı'nda (Hüsrev Paşa Hanı), her iki katta da yer alan revakların arkasında birer tane han odası bulunmaktadır. Odaların duvarlarında küçük nişler vardır. Bu odalar revaklara, birer kapı ve birer pencereyle açılmaktadır. Kap1 ve pencereler dikdörtgen biçimli olup, kenarları siyah-beyaz taş sıralarıyla almaşık olarak örülmüştür. Merdivenlerin başında yer alanlar basık kemerli olup, kemerleri almaşık örgülüdür. Odanın önünde bulunan revaklı kısmın üst örtüsü revakların ayaklarına kadar inerek buraya eyvan görünümü vermekte, ayaklardan geriye kalan bölüm basık kemerli bir açıklık olarak öteki yöne geçit sağlamaktadır. Hanın giriş kapısının üzerindeki yazıda hanın 72 odadan ve 17 dükkandan oluştuğu kaydedilmektedir. Hasan Paşa Hanı'nda aynı düzenleme görülmekte, her iki katta da revakların arkasında birer han odası bulunmaktadır. Odaların önünde boydan boya yer alan revaklı kısım, tonoz binginin ve duvarlara oturan ayak kısımlarının sağladığı baldaken tarzda bir görünüme sahiptir. Revakların köşelerde bulunan kısımlarında sütun gövdesi yapılmayıp revakların alt kısımları boş bırakılarak iki yarım sütun şeklini almaştır. Revakların gerisinde yer alan odaların, dikdörtgen biçimli birer kapısı ve bir penceresi bulunmaktadır. Odaların üst örtüsünde kubbe içi ve pandantifler tuğla-taş malzeme birlikte kullanılarak oluşturulmuştur. Odaların içinde niş bulunmamaktadır. Çifte Han'da, üst kattaki han odalarının önünde de revaklar bulunmaktadır. Odaların avluya bakan yüzlerinde, üstü düz taş hatıllı bir kap1 ve bir pencere yer almaktadır. Odaların dış mekana bakan yüzlerinde dikdörtgen formlu ve yuvarlak kemerli üçer pencere yer al- 
maktadır. Odaların içinde ise duvarlarda nişler yer almaktadır. Odaların üstü ahşap kirişlidir.

Deliller Hanı'nda (Hüsrev Paşa Hanı), hanın ahır ve depo olarak kullanılan ikinci kısmı, yapının güneyinde yer almakta ve bu mekana bir han odası geçit vermektedir. Ahır bölümü, girişe paralel kemerlerin beş ayak sırasını birbirine bağlayarak altı nefe bölmesiyle şekillenmiştir. Duvarlarında tek sıra pencereler aydınlatmayı sağmakta, ancak tek sıra olarak açıldıklarından dolayı yeterli olmamakta ve içerisi biraz loş kalmaktadır. Ahır bölümünde, doğu-batı yönünde uzanan kemerlerin aralarındaki neflerin üzeri boydan boya beşik tonozludur. Hanın giriş kapısının üzerindeki yazıda ahır bölümünün 800 deve alabilecek kapasitede olduğu belirtilmektedir. Hasan Paşa Hanı, ahır bölümü ise yapının bodrumunda bulunmaktadır. Burası kalın ayaklarla altı nefe bölünmüştür. $\mathrm{Bu}$ kısma duvarlara açılan mazgal pencereleriyle gerekli 1şık sağlanmaya çalışı1mıştır. Bu nedenle burası da bir hayli loştur. Polonyalı Simeon, "muazzam kargir bir bina olan bu hanın 500 beygiri barındirabilen yeraltında iki büyük ahırı" (Andreasyan, 1964, s. 98) bulunduğundan bahsetmektedir. Çifte Han'ın ahır bölümü bugün mevcut değildir.

Diyarbakır'da Osmanlı döneminde inşa edilen hanlardan günümüze ulaşan Deliller Hanı (Hüsrev Paşa Hanı) ile Hasan Paşa Hanı'nda süsleme unsurları kullanılmıştır. Çifte Han'da ise süslemeden kaçınılmıştır. Deliller (Hüsrev Paşa) Hanı'nda süsleme dış mimaride sadece batı cephede, iç mekânda ise giriş eyvanı ile aynı aks üzerinde yer alan eyvanın üst bölümünde yer alan iki kare panoda görülmektedir. Bunların dışında süslemenin görülmediği avlu cepheleri iki renkli taşların almaşı örülmesiyle hareketlendirilmiştir. Hasan Paşa Hanı'nda bütün dış cephelerde süsleme kullanılmıştır. Çifte Han ise bu iki Osmanlı hanına göre oldukça yalın kalmaktadır.

Osmanlı imparatorluğu 16. yy.'da en görkemli çağını yaşamış ve 17. yüzyıldan itibaren durgunluğa bürünmüş, 19. yy.'da toparlanma çabalarına girişilmiş ve nihayetinde de iyiden iyiye zayıflamış ve kaçınılmaz sona doğru ilerlemiştir. Bu dönemlere ait R. Arslan'ın (1999, s. 92) tespitleri bu aşamaları ve Diyarbakır ticaret hayatının gidişatını çok güzel özetlemektedir. Arslan, bazıları sübjektif olmakla birlikte gezginlerin gözlemleri ve verdikleri bazı somut bilgiler; Diyarbakır ile bağlantısı olan klasik ticaret yollarının eski etkinliğini yitirerek önemsiz hale gelmesi; imparatorluk ekonomisinin 17. yy.'dan başlayarak 18. ve 19. yy.'larda daha da fazla çökmesi; Avrupa mallarıyla rekabet edemeyen yerel üretimlerin iflas etmesi; kervan yolları üzerinde bulunan tüm ticaret kentlerini olduğu gibi Diyarbakır'ı da olumsuz etkilediğini belirtmektedir. $\mathrm{Bu}$ durumdan mekansal olarak ilk etkilenen ise hanlar olmuştur. Ticaret, üretim, barınma gibi fonksiyonları bulunan hanların ticari cansızlıktan ötürü atıl vaziyette kalması sonucu ya işlevinin değiştirildiği, ya askeri amaçlara 
ayrılmış olduğu ya da bakımsızlığa terk edildiği saptanmaktadır. Bu durum da isimleri bilinen bazı hanların günümüze ulaşamaması sonucunu doğurmuştur (Tablo:1-Çiz.4).

\subsection{Mimari Elemanlar}

\subsubsection{Taçkapı ve Girişler}

Taç kapılar, genellikle önemli bir mimari esere geçit veren anıtsal kapılardır. Diyarbakır'daki Osmanlı dönemi mimari yapılarında kapılar Anadolu'nun öteki bölgelerine göre daha arka planda kalmakta (Arık, 1971, s. 12; Bayburtluoğlu, 1976, s. 68; Ünal, 1982, s. 17), üzerinde yer aldığı yapıyla uyumlu ölçülerde, süslemede belli bir denge içinde ve yerel etkilerin baskın olduğu bir görünümde ortaya çıkmaktadırlar. Osmanlı dönemine ait Hasan Paşa Hanı yoğun süslemeli taçkapılara sahiptir. Hanın avlusuna ulaşmayı sağlayan ve sivri kemerli eyvanlar içine yerleştirilen üç kapısı da farklı süslemeli bordürler, mukarnas şeritler, mukarnas kavsaralı nişler ve bezemeli sütunceler içermektedir. Deliller Hanı'nın cepheden taşıntılı ve çıkıntılı tutularak vurgulanan sivri kemerli eyvan şeklindeki taçkapısı, Hasan Paşa Hanı'nın batı girişi ile benzeşmektedir. Aralarındaki fark Hasan Paşa hanının taçkapısının cepheyle aynı düzlemde olup, taşkınlık yapmamasıdır. Çifte Han'da, yapının ilk şekli çifte han olarak düşünülüp yapıldığından giriş kısmı ve ikinci hana geçiş kısmı ana eksen üzerinde olmayıp, sağa kaydırılmıştır. Giriş kapısı geniş basık kemerli olup, buradan girilen kısım bir ara mekan şeklinde düzenlenmiştir.

\subsection{Malzeme Ve Teknik}

Mimaride malzeme olarak o yörede en bol bulunan yapı gereci tercih edilmektedir. Anadolu mimarisinde ve Diyarbakır'da da ilk dönemlerden itibaren kullanılan taş, hemen her dönemde mimarinin ana malzemesi konumunda olmuştur. Diğer malzemeler (tuğla, mermer, ahşap, alçı ve çini) yapının işlev ve önemine göre değişik yerlerinde uygulanmışlardır.

Bölgenin jeolojik yapısından dolayı işlev ve boyut farkı gözetilmeksizin hemen hemen bütün yapı türlerinde kullanılan başlıca malzeme bazalt taştır. Bu taş delikli (dişi bazalt taşı) ve deliksiz (erkek bazalt taşı) olmak üzere iki türlüdür. Diyarbakır'ın anıtsal mimarisinde bölgenin karakteristik yapı taşı olan bazalt ile yapılarda Suriye için karakteristik siyah-beyaz alterne taş kaplama yaygın olarak kullanılmıştır (Kuban, 2007, s. 573). Diyarbakır yapılarının genelinde ve hanlarda kullanılan iki renkli (siyah-beyaz) düzgün kesme taş mahalli üslup olup Zengi sanatının etkisini göstermektedir. 1890-1897 yılları arasında Diyarbakır'a gelen Edmund Naumann, Diyarbakır'ın koyu 
gri bazalt taştan inşa edildiğini, kalenin, hanların ve bazı evlerin duvarlarının iri ve özenle işlenmiş taşlardan yapılmasının hayret verici olduğunu, taşların işlenmesinin olduğu kadar bu taşları üst üste koymanın da büyük bir emek gerektirdiğini ifade etmektedir (Pınar, 1999). Diyarbakır'da kullanılan ikinci taş türü kireç taşı olarak da bilinen ve Ergani bölgesinde yoğun olarak bulunan açık sarı renkli kalkerdir (Tuncer, 1996, s. 191).

Diyarbakır Deliller Hanı ve Hasan Paşa Hanı'nda iki renkli taş kullanılmıştır. Deliller Hanı'nda ayrıca moloz taş ve tuğla malzemeye de yer verilmiştir. Hanın giriş kapısının üzerindeki yazıdan beyaz taşların Urfa'dan, siyah taşların ise Kurtboğaz taş ocağından çıkartıldığı öğrenilmektedir. Hasan Paşa Hanı'nda iki renkli kesme taş (siyah-beyaz bazalt taş) ve sarı kalker taşı kullanılmıştır. Ayrıca giriş eyvanının, odaların ve ahır bölümünün tavanlarında tuğla malzemeye yer verilmiştir. Tuğla malzemenin araları beyaz derzlerle kapatılmıştır. Urfa Gümrük Hanı'nın da doğu ve kuzey cephelerinde, üst kat doğu revakının gerisindeki duvarlarda, bir sıra bazalt ve bir sira küfeki taşının yatay olarak kullanılmasının cephelere hareketli bir görünüm kazandırdığı, benzer uygulamaların Gaziantep Merkez Hişva Hanı, Elbeyli Hanı, Yeni Han, Şam Süleyman Paşa Hanı, Esat Paşa Hanı, Çakmak Han ile Halep Vezir Han'da görüldügü belirtilmektedir (Özme, 2000, s. 85). Çifte Han tamamen siyah kesme bazalt taşından yapılmıştır. Yapıda, bezemesiz yalın başlıkların oturduğu sütunlar beyaz taştandır. Avlusu ise siyah kesme taşlarla döşenmiştir.

\subsection{Süsleme}

Hanlarda süsleme unsuru daha çok yapım gereci olarak taşın iki renkli olarak almaşık örgülü kullanımının sağladığı hareketlilik olarak elde edilmiş, mimari süslemeye belli oranda yer verilmiştir. Pencerelerin üstlerini örten bas1k kemerlerde iki renkli taşlar ters-düz palmet motifleri oluşturacak şekilde yerleştirilmişlerdir.

\subsubsection{Bitkisel Süsleme}

Deliller Hanı'nda (Hüsrev Paşa Hanı), aynı zamanda giriş cephesi de olan batı cephe süslemenin yoğunlaştığı cephedir. Bu cephenin orta bölümü, iki renkli taş işçiliğinin yoğun kullanımı nedeniyle sade bazaltla inşa edilen yan kenarlardan belirgin bir şekilde ayırt edilmekte ve kuvvetle vurgulanmaktadır. Cephenin tam ortasında, girişteki eyvan kemerinin üst bölümünde yer alan iki adet pencere nişler içine alınmıştır. Pencerelerin üstlerini örten basık kemerler ise iki renkli taşlarla geçmeli olarak düzenlenmiş olup, taşlar tersdüz palmet motifleri oluşturmaktadır. Pencerelerin arasında, diştan siyah ba- 
zaltla oluşturulmuş silmelerle sınırlandırılan zemini sarı kalkerden olan kare formlu bir pano bulunmaktadır. Eyvan kemerinin dış köşeleri gömme sütunceler ile belirtilmiştir. Sütuncelerin gövdelerinde geometrik örgü motifleri yer almaktadır. Eyvanın yan duvarlarında, beşgen planlı nişler şeklinde olup, süsleme yönünden küçük farklarla birbirini tekrar eden birer mihrabiyeye yer verilmiştir. Mukarnas kavsara ile örtülen ve üstte üç dilimli kemerlerle sonlanan nişleri dıştan geometrik bordürler dört yönde dolanmaktadır. Nişlerin etrafı iki farklı bordürle çevrelenmiş olup, üzerlerinde üç şeritli örgü, çapraz olarak kesişen ikili örgülerin zeminde sekiz köşeli yıldızlar meydana getirmesi ve yıldızların içine yerleştirilen gülbezek motifleri tarzında geometrik ve bitkisel karakterli bezeme unsurları yer almaktadır. Kuzey taraftaki nişin mukarnas kavsarası sekiz sıradan, güneyde yer alan nişin mukarnas kavsarası ise altı sıradan oluşmaktadır. Nişlerin üstünde de baklava dilimi şeklinde yerleştirilen makıli hatlı bir yazı panosu yer almaktadır. Eyvan nişinin ortasında yer alan basık kemerli asıl giriş kapısının üstünde dıştan üç farklı düzenleme gösteren bordürlerin çevrelediği, yatay dikdörtgen bir kitabe panosu bulunmaktadir.

Hasan Paşa Hanı'nda da giriş eyvanının dış köşeliklerine birer gömme sütunce yerleştirilmiştir. Silindirik gövdeli sütuncelerin başlıkları bitkisel bezemelidir. Giriş eyvanının içinde yer alan asıl giriş kapısının üzerinde yatay biçimde yerleştirilmiş dikdörtgen formlu bir kitabenin etrafinda iki sıra mukarnas dizisi bulunmakta, ikinci mukarnas sırasının köşelerine birer gülbezek motifi yerleştirildiği görülmektedir. Hasan Paşa Hanı'nın aynı zamanda giriş cephesi olan batı cephesinde giriş bölümünün iki yanında üstte yer alan altışar pencere çeşitli süsleme unsurları taşımaktadır.

\subsubsection{Geometrik Süsleme}

Deliller Hanı'nda (Hüsrev Paşa Hanı), aynı zamanda giriş cephesi de olan batı cephede eyvan kemerinin dış köşeleri gömme sütunceler ile belirtilmiş olup, sütuncelerin gövdelerinde geometrik örgü motifleri yer almaktadır. Eyvanın yan duvarlarında, beşgen planlı nişler şeklinde olup, süsleme yönünden küçük farklarla birbirini tekrar eden birer mihrabiyeye yer verilmiştir. Nişleri dıştan geometrik bordürler dört yönde dolanmaktadır. Nişlerin etrafi iki farklı bordürle çevrelenmiş olup, üzerlerinde üç şeritli örgü, çapraz olarak kesişen ikili örgülerin zeminde sekiz köşeli yıldızlar meydana getirmesi ve yıldızların içine yerleştirilen gülbezek motifleri tarzında geometrik ve bitkisel karakterli bezeme unsurları yer almaktadır. Deliller Hanı'nda (Hüsrev Paşa Hanı) ayrıca girişin karşısındaki cephede bulunan eyvanın üzerinde beyaz kalker zemin 
üzerine bazalt harflerin yerleştirildiği, dıştan dişli şeklinde iki niş sırasının ince bir bordür şeklinde sınırladığı iki kare pano yer almaktadır.

Hasan Paşa Hanı'nda, giriş eyvanının içinde yer alan asıl giriş kapısının üzerinde yatay biçimde yerleştirilmiş dikdörtgen formlu bir kitabenin etrafi bir sıra geometrik düzenlemeyle sınırlanmaktadır. Hasan Paşa Hanı'nda, giriş eyvanının üst kesiminde Deliller Hanı'ndaki gibi iki pencere bulunmaktadır. Dikdörtgen nişler içine yerleştirilen pencereler basık kemerlerle örtülmüştür. Basık kemerler aynı boyuttaki ters-düz palmetlerden oluşan iki renkli taşlarla geçmeli olarak düzenlenmiştir. Yalnız geçme taşlar sol pencerede beyaz zemin üzerine siyahla, sağ pencerede ise bunun tam tersi siyah zemin üzerine beyazla oluşturulmuştur. Hasan Paşa Hanı'nda, giriş eyvanının üst kesiminde bulunan iki adet pencerenin nişlerinin köşeliklerine silindirik gövdeleri iri örgülerle kaplanmış olan birer sütunce yerleştirilmiştir. Sivri kemerli eyvanın üstündeki iki pencere arasına iki geometrik bordürün oluşturduğu bir çerçeve bulunmaktadır. Yapının farklı çarşı yapıları ile bağlantılı olan doğu cephesinin ortasında bulunan yuvarlak kemerli eyvan şeklinde düzenlenen ikinci giriş bölümü de oldukça yoğun bir şekilde süslenmiştir. Burada da eyvanın dış köşeliklerinde silindirik gövdeleri geometrik bir kompozisyonla kaplanmış birer gömme sütunceye yer verilmiştir. Hasan Paşa Hanı'nın doğu cephesinin ortasında bulunan yuvarlak kemerli eyvan şeklinde düzenlenen ikinci giriş bölümündeki eyvanın yan duvarlarındaki çokgen planlı birer nişin üzerinde yuvarlak formlu ve yüzeylerinde aynı geometrik kompozisyonu barındıran birer madalyon bulunmaktadır.

\subsubsection{Mukarnas}

Deliller Hanı'nda (Hüsrev Paşa Hanı), aynı zamanda giriş cephesi de olan batı cephe süslemenin yoğunlaştığı cephedir. Bu cephenin orta bölümü, iki renkli taş işçiliğinin yoğun kullanımı nedeniyle sade bazaltla inşa edilen yan kenarlardan belirgin bir şekilde ayırt edilmekte ve kuvvetle vurgulanmaktadır. Cephenin tam ortasında, girişteki eyvan kemerinin üst bölümünde yer alan iki adet pencerenin nişleri üstte mukarnas dizileri ile sonlanmaktadır. Eyvan şeklindeki taçkapının yan duvarlarında, beşgen planlı nişler şeklinde olup, süsleme yönünden küçük farklarla birbirini tekrar eden birer mihrabiye mukarnas kavsaralıdır. Kuzey taraftaki nişin mukarnas kavsarası sekiz sıradan, güneyde yer alan nişin mukarnas kavsarası ise altı sıradan oluşmaktadır. Hasan Paşa Hanı'nda, giriş eyvanının içinde yer alan asıl giriş kapısının üzerinde yatay biçimde yerleştirilmiş dikdörtgen formlu bir kitabenin etrafında iki sıra mukarnas dizisi yer almaktadır. Hasan Paşa Hanı'nda, giriş eyvanının üst kesiminde bulunan iki adet pencerenin nişleri dört mukarnas sırasıyla sonlanmaktadır. 
Hasan Paşa Hanı'nın doğu cephesinin ortasında bulunan yuvarlak kemerli eyvan şeklinde düzenlenen ikinci giriş bölümünde, eyvanın dış köşeliklerinde silindirik gövdeleri geometrik bir kompozisyonla kaplanmış birer gömme sütunceye yer verilmiştir. Eyvanın yan duvarlarında çokgen planlı birer niş yer almaktadır. Nişlerin üzerindeki mukarnas kavsaralardan kuzey taraftaki on sıradan güney taraftaki ise dokuz sıradan meydana gelmektedir. Mukarnas kavsaralar üstten üç dilimli birer kemerle sonlanmaktadır.

\subsubsection{Yazı}

Türk-İ́slam Sanatında olduğu gibi Diyarbakır yapılarında da yazının ayrı bir yeri vardır. Deliller Hanı'nda (Hüsrev Paşa Hanı), eyvan şeklindeki taçkapının yan duvarlarındaki nişlerin üstünde baklava dilimi şeklinde yerleştirilen makıli hatlı bir yazı panosu yer almaktadır. Eyvan nişinin ortasında yer alan basık kemerli asıl giriş kapısının üstünde dıştan üç farklı düzenleme gösteren bordürlerin çevrelediği, yatay dikdörtgen bir kitabe panosu bulunmaktadır. Hasan Paşa Hanı'nda, giriş eyvanının içinde yer alan asıl giriş kapısının üzerinde yatay biçimde yerleştirilmiş dikdörtgen formlu bir kitabe bulunmaktadır. Kitabe, celi sülüs hatla iki satır olarak yazılmıştır. Hasan Paşa Hanı'nda, sivri kemerli giriş eyvanının üstündeki iki pencere arasına çerçeve içinde yer alan beyaz kalker zemin üzerine siyah bazalttan makıli yazıların olduğu büyük boyutlu kare bir yazı panosu yerleştirilmiştir. Hasan Paşa Hanı'nın doğu cephesinin ortasında bulunan yuvarlak kemerli eyvan şeklinde düzenlenen ikinci giriş bölümündeki eyvanın içinde bulunan basık kemerli kapının üstünde mukarnas bordürün üst kesiminde dikdörtgen biçimli ve üç farklı bordürden meydana gelen bir çerçeve içinde Celi sülüs hatlı altı satırlık bir kitabe yer almaktadır. Yazılar kenarlarda üç dilimli sonlanan kartuşlar içine yerleştirilmiştir.

\section{Sonuç}

Bu çalışmada, Diyarbakır suriçinde Osmanlı Döneminde inşa edilen mimari yapılardan tarihi hanlar incelenmeye ve bu dönemde kenti ziyaret etmiş olan seyyahların izlenimleri eşliğinde verilmeye çalışılmıştır. Çalışma kapsamında 3 tarihi han ele alınmıştır. Eserlerin yoğunluk alanı Diyarbakır merkezindeki sur içidir.

Diyarbakır'ın Tarihi İpek Yolu'nun merkezlerinden biri olması önemli hanlara sahip olma sonucunu doğurmuştur. Diyarbakır'ın konumu itibariyle büyük ve önemli bölgeleri birbirine bağlayan ana yolların kavşağında bulunması hanların yapımını gerekli kılmıştır. Diyarbakır'da günümüzde de varlığını sürdüren hanlar Osmanlılar döneminde yapılmış olup, bu devrin 
mimarisinin en güzel örneklerindendir. Bugün ayakta kalan ve kentin içinde yer alan Osmanlı Dönemi hanları, Deliller Hanı (Hüsrev Paşa Hanı/Kervansaray), Hasan Paşa Hanı ve Çifte Han'dır. Bu şehir içi hanları genellikle ortadaki şadırvanlı bir avlunun çevresinde sıralanan revakların arkasında iki katlı han odalarının yer alması şeklinde bir plan şemasına sahiptirler. Hasan Paşa Hanı mimari ve süsleme açısından Deliller Hanı'nın izleyicisidir. Ortada şadırvanlı bir avlu, çevresinde iki katlı han odaları ve bir bölüm şeklinde büyük ahır kısmıyla Hasan Paşa Hanı Osmanlı devri hanlarının genel gelişim çizgisi içinde yer almaktadır. Osmanlı Dönemi’nin bu iki önemli hanı, genel gelişim çizgisi içinde yer almakta, kufi yazıların, siyah-beyaz taş sıralarının şekillendirmesiyle bölgesel özellikleri de bünyelerinde barındırmaktadır. Çifte Han'da bu iki han gibi bir orta avlunun çevresinde şekillenmiştir. Ancak dış ve iç görünüşüyle diğerlerinin aksine çok daha yalın ele alınmış, süslemeden de kaçınılmıştır.

Osmanlı döneminde adını taşıdığı beylerbeyliğinin merkezi olarak bölgedeki önemli stratejik noktalardan biri olan Diyarbakır'daki Osmanlı eserleri, Güneydoğu Anadolu Bölgesi içinde Osmanlı kimliğini en güçlü yansıtan örnekler arasındadır. Diyarbakır Osmanlı dönemine ait yapılarda, Osmanlı mimarisinin özgün çizgileri yerel mimari ile kaynaşmıştır. Yerel gereç kullanımı ile yörenin geçmişi yüzyıllar öncesine dayanan mimari geleneği Osmanlı potasında birleşerek Diyarbakır'a özgü muhteşem bir mimari üslup yaratılmıştır. Osmanlı formlarının ve mekan anlayışının, bölgedeki Ermeni ve Suriye mimari geleneklerine dayanması ve yerel mimarlık anlayışlarıyla birleşmesi, Diyarbakır'daki büyük Osmanlı yapılarına kendine özgü havayı kazandırmıştır. Diyarbakır Osmanlı Dönemi Mimarisi'nde kullanılan yerel gereç, iklim özelliklerinin yapılara yansıması ve bezemedeki ayrıntılar şeklindeki bölgesel özellikler mimaride yoğun olarak varlığını duyurmaktadır. $\mathrm{Bu}$ özellikler süreklilik göstererek bir bütünlük duygusu yaratmıştır. Bölgenin geleneksel yapı malzemesinin taş olması sebebiyle yapılarda bazalt, kalker, mermer kullanılmıştır. Yapılardaki bezemelerde ise Osmanlı öncesi sanat gelenekleri ile yerli özelliklerin de etkili olduğu görülmektedir. Üslubu, farklı malzemesi ve yapıya gösterilen özen sayesinde Diyarbakır mimarisi Anadolu'daki en çekici ve farklı mimari tarzlardan birini oluşturmaktadır. Osmanlı dönemine ait hanlar da bu özellikleri bünyelerinde barındırmakta ve çok yönlü etkiler, zengin ve köklü bir gelenek içinde eşsiz birer mücevher niteliğinde parlamaktadırlar. 
86 • YALOVA SOSYAL BİLIMLER DERGİSİ

\section{Tablolar:}

Tablo 1: Osmanlı Döneminde Diyarbakır'da Mevcut ve Mevcut Olmayan Hanlar (Çizim:4)

1. Hasan Paşa Hanı

2. Deliller Hanı

3. Çifte Han

4. Rüstem Paşa Hanı

5. İbrahim Paşa Hanı

6. Tütün Hanı

7. Karakaş Hanı

8. Kayseriye Han

9. İpekoğlu Hanı

10. Melek Ahmet Paşa Hanı

11. Han-1 Cedid

\section{4. Çizimler:}

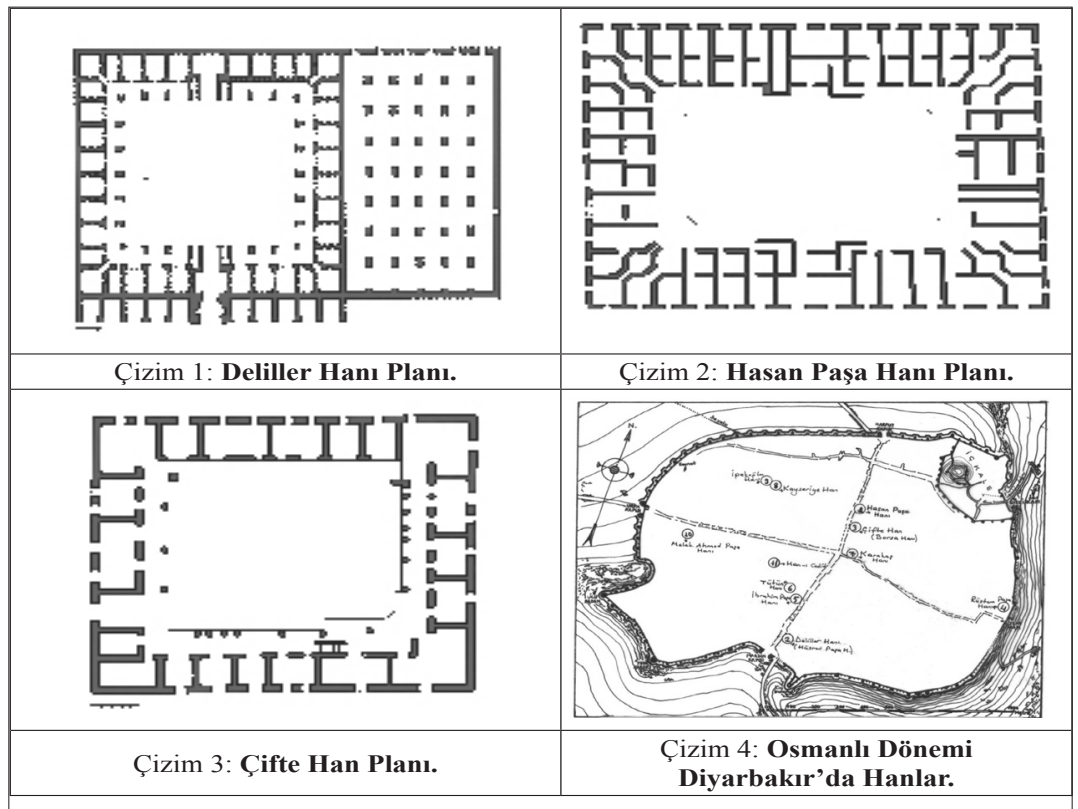




\section{Fotoğraflar:}
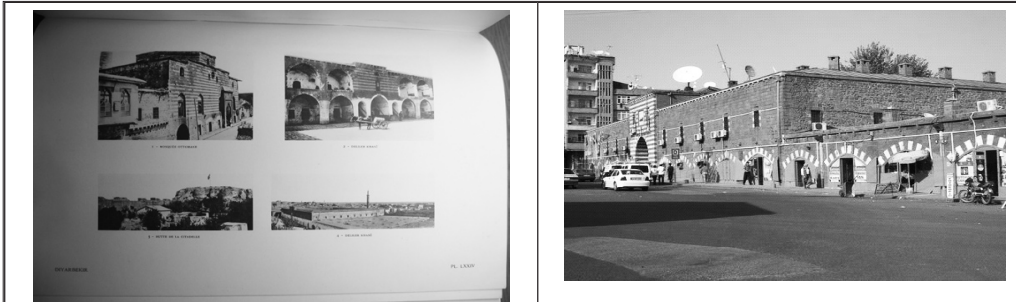

Fotoğraf 1: Deliller Hanı, (Gabriel, 1940).

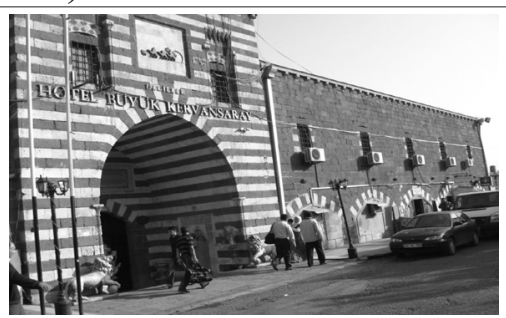

Fotoğraf 2: Deliller Hanı Giriş Cephesi.

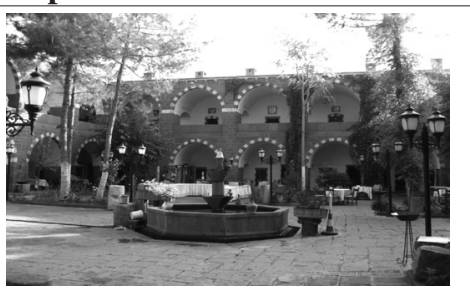

Fotoğraf 3: Deliller Hanı Taç Kapısı.

Fotoğraf 4: Deliller Hanı Avlusu.

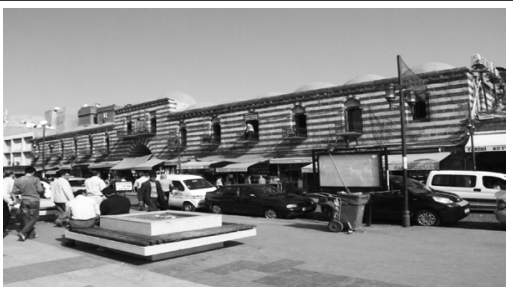

Fotoğraf 5: Hasan Paşa Hanı Giriş Cephesi.

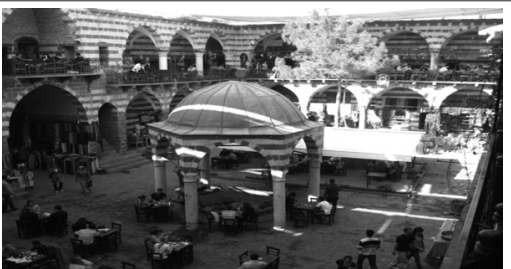

Fotoğraf 7: Hasan Paşa Hanı Avlusu.
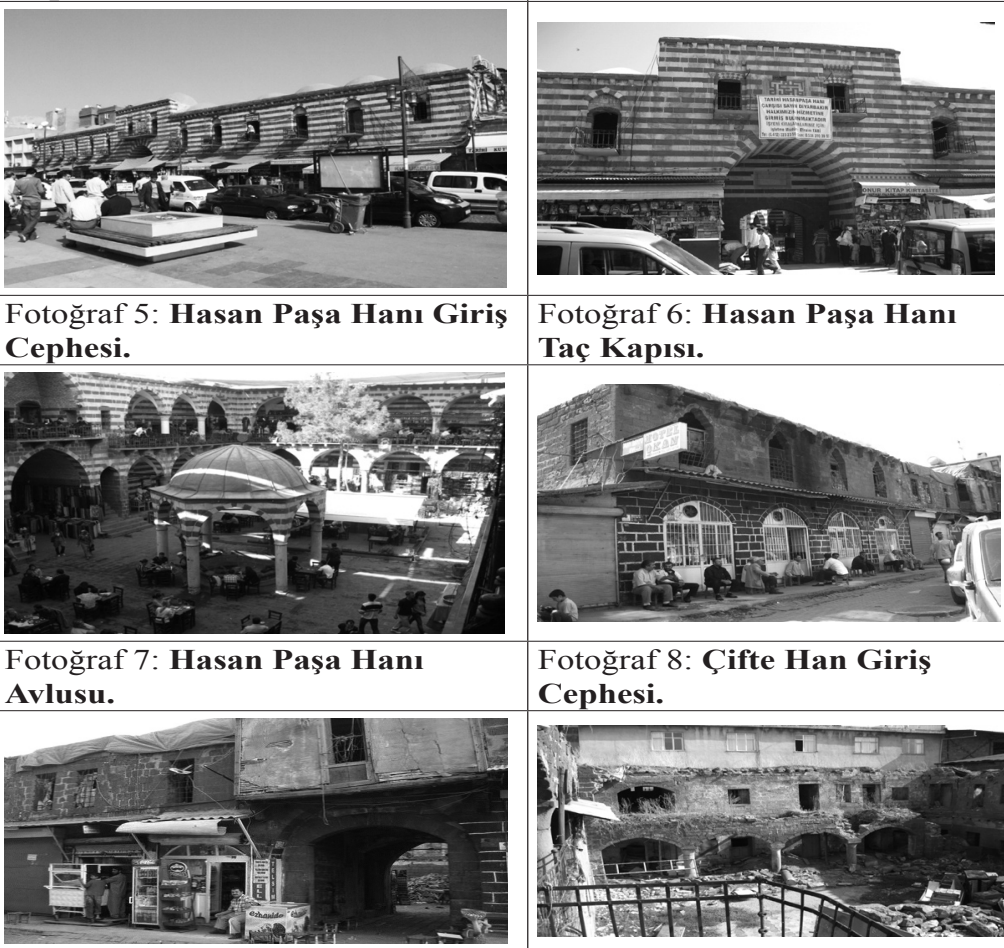

Fotoğraf 6: Hasan Paşa Hanı Taç Kapısı.

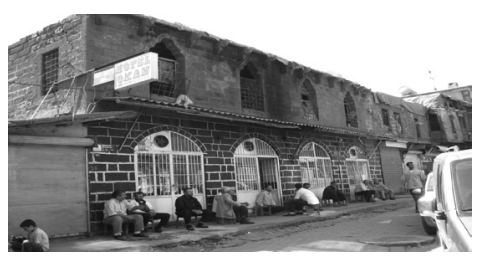

Fotoğraf 8: Çifte Han Giriş Cephesi.

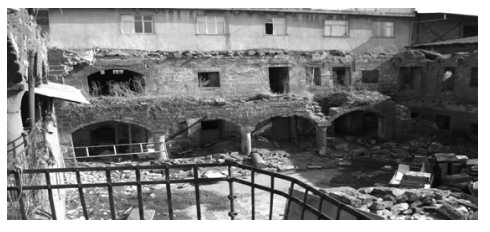

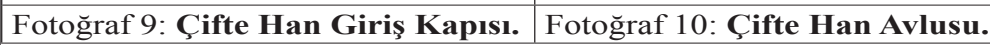




\section{Kaynaklar:}

AKBULUT, İ. (1998). Diyarbakır. İstanbul, Diyarbakır Büyükşehir Belediyesi Yayını.

ALTUN, A. (1994). Deliller Hanı. Türkiye Diyanet Vakfi İslam Ansiklopedisi, 9, içinde, (ss. 140-141). İstanbul, Türkiye Diyanet Vakfi.

ANDREASYAN, H. D. (1964). Polonyalı Simeon'un Seyahatnâmesi, İstanbul: Baha Matbaas1.

ARIK, O. (1971). Anadolu'daki Mimari Tezyinatımızda Arkaik Karakter. Önasya, VI-72, $10-21$.

ARSLAN, R. (Aralık 1999). Diyarbakır Kentinin Tarihi ve Bugünkü Konumu. Selahattin Özpalabıyıklar (Ed.). Diyarbakır: Müze Şehir içinde, (ss. 81-107). İstanbul: Yapı Kredi Yayınları.

BAŞ, G. (2006). Diyarbakır'daki İslam Dönemi Mimarisinde Süsleme. Yüzüncü Y1l Üniversitesi Sosyal Bilimler Enstitüsü, Yayımlanmamış Doktora Tezi, Van.

BAYBURTLUOĞLU, Z. (1976). Anadolu Selçuklu Devri Büyük Programlı Yapılarında Ön Yüz Düzeni, Vakıflar Dergisi, 11, 67-106.

BEYSANOĞLU, Ş. (1996). Diyarbakır Tarihi. Ankara, Diyarbakır Büyükşehir Belediyesi Yayın1.

BEYSANOĞLU, Ş. (1998). Anıtları ve Kitabeleri ile Diyarbakır Tarihi, 2, Ankara, Irmak Matbaas1.

BEYSANOĞLU, Ş. (2003). Anıtları ve Kitabeleri ile Diyarbakır Tarihi, 3 Cilt, Ankara, Diyarbakır Büyükşehir Belediyesi Kültür ve Sanat Yayını.

BUCKINGHAM, J. S. (1827). Travels in Mesopotamia, London, Henry Colburn, New Burlington Street.

BULDUK, Ü. (2008). Hülasa-i Ahvali'l-Buldan'a Göre 19. Yüzyılda Diyarbakır Şehri. Bahaeddin Yediyıldız-Kerstin Tomenendal (Ed.). Osmanlı'dan Cumhuriyet'e Diyarbakır, I, içinde (ss. 187-197). Ankara, Diyarbakır Valiliği Yayınları.

CUINET, V. (1891). La Turquie D'asie Geographie Administrative, Statistique, Descriptive et Raisonnée de Chague Province l'Asie-Mineure, II, Paris, Ernest Leroux.

DUCKETT, W. (1855). La Turquie Pittoresque. Paris, Victor Lecou.

ERSOY, B. (1995). Diyarbakır Deliller Han1. Kültür ve Sanat, 28, 21-23.

EVLIYA ÇELEBİ, (1970). Evliyâ Çelebi Seyahatnâmesi, 6. (Zuhurî Danışman, Çev.). İstanbul, Zuhuri Danışman Yayını.

GABRIEL, A.-L. (1940). Voyages Archéologiques Dans la Turquie Orientale, II Planches. Paris, E. De Boccard, Planche LXXIV.

GARDEN, R. J. (1867). Description of Diarbekr. Journal of the Royal Geographical Society, 37, 182.193 .

GARDEN, R. J. (Aralık 1999). Diyarbakır. (Hamdi Can Tuncer, Çev). Selahattin Özpalabıyıklar (Ed.). Diyarbakır: Müze Şehir içinde, (ss. 138-145). İstanbul, Yapı Kredi Yayınları.

KÖPRÜLÜ, İ. (1987). Diyarbakır Deliller Hanı'nın Otel Olarak Düzenlenmesi. II. Vaklf Haftasl, Ankara. 
KUBAN, D. (2007). Osmanlı Mimarisi. İstanbul, Yem Yayın.

MOLTKE, H. V. (1877). Zustaende und Begebenheiten in der Türkei aus den Jahren 1835 bis 1839. Berlin, Ernst Siegfried Mitler und Sohn.

ÖZME, A. (2000). Urfa (Merkez) Hanları. Ankara Üniversitesi Sosyal Bilimler Enstitüsü, Yayımlanmamış Doktora Tezi, Ankara.

PARLA, C. (1990). Türk İslam Şehri Olarak Diyarbakır. Hacettepe Üniversitesi Sosyal Bilimler Enstitüsü, Yayımlanmamış Yüksek Lisans Tezi, Ankara.

PINAR, İ. (Aralık 1999). Gezginlerin Gözüyle Diyarbakır (1701-1924). Selahattin Özpalabıyıklar (Ed.). Diyarbakır: Müze Şehir içinde, (ss. 146-163). İstanbul, Yapı Kredi Yayınları.

SARI, İ. (1996). Şehrimiz Diyarbakır. İstanbul, Diyarbakır Büyükşehir Belediyesi Kültür Yayınlar1.

SCHWEIGER-LERCHENFELD, A. V. (1882). Der Orient. Wien-Pest-Leipzig, A. Hartleben's Verlag.

SÖZEN, M. (1971). Diyarbakır'da Türk Mimarisi. İstanbul, Diyarbakır'1 Tanıtma ve Turizm Yayını.

SÖZEN, M., (Ed.). (1975). Türk Mimarisinin Gelişimi ve Mimar Sinan. İstanbul, Türkiye İş Bankası Kültür Yayınları.

TAVERNIER, J. B. (1692). Les six Voyages de Jean Baptiste Tavernier, en Turquie en Perse et aux Indes, I. Paris, Chez Gervais Clouzier.

TUNCEL, M. (1994). Bugünkü Diyarbakır. Türkiye Diyanet Vakfi İslam Ansiklopedisi, 9 , içinde, (ss. s. 469-472). İstanbul, Türkiye Diyanet Vakfi Yayınları.

TUNCER, O. C. (1996). Diyarbakır Camileri. Ankara, Diyarbakır Büyükşehir Belediyesi, Kültür ve Sanat Yayınları.

ÜNAL, R. H. (1982). Osmanlı Öncesi Anadolu Türk Mimarisinde Taçkapılar. İzmir, Ege Üniversitesi Yayınevi.

YALÇINER, G. (1997). Han. Eczacıbaşı Sanat Ansiklopedisi, II, (ss. 753-754). İstanbul, Yap1 Endüstri Merkezi.

YILDIRIM, M. (1996). Diyarbakır Hasan Paşa Hanı Koruma ve Değerlendirilmesi. Yıldız Teknik Üniversitesi Sosyal Bilimler Enstitüsü, Yayımlanmamış Yüksek Lisans Tezi, İstanbul.

YILMAZÇELİK, İ. (Aralık 1999). Osmanlı Hakimiyeti Süresince Diyarbekir Eyaletinin İktisadi ve Sosyal Durumu. Selahattin Özpalabıyıklar (Ed.). Diyarbakır: Müze Şehir içinde, (ss. 470-512). İstanbul: Yap1 Kredi Yayınları.

WARKWORTH, Lord M.P. (1898). Notes From a Diary in Asiatic Turkey. London, Edward Arnold.

2000'e Beş Kala Diyarbakır. (1995). Diyarbakır, Diyarbakır Valiliği Yayını. 